Canadian Journal of Applied Linguistics

Revue canadienne de linguistique appliquée

\title{
Understanding the Relationship Between Second Language Teacher Beliefs and Their Instructional Practices: A Case Study of Core French Teachers
}

\author{
Usha Viswanathan
}

Volume 22, Number 1, 2019

Special Issue: In Memory of Larry Vandergrift

Numéro spécial : à la mémoire de Larry Vandergrift

URI: https://id.erudit.org/iderudit/1060905ar

DOI: https://doi.org/10.7202/1060905ar

See table of contents

Publisher(s)

University of New Brunswick

ISSN

1920-1818 (digital)

Explore this journal

Cite this article

Viswanathan, U. (2019). Understanding the Relationship Between Second Language Teacher Beliefs and Their Instructional Practices: A Case Study of Core French Teachers. Canadian Journal of Applied Linguistics / Revue canadienne de linguistique appliquée, 22(1). https://doi.org/10.7202/1060905ar

\section{Article abstract}

This study explores the relationship between Core French teachers' beliefs and their instructional practices. In the literature, contextual elements, as well as the compatibility between teacher beliefs and second language teaching approaches such as communicative language teaching (CLT) have been regularly cited as key factors contributing to discrepancy between beliefs and practices. However, these factors did not adequately explain what I had witnessed as a teacher educator. To explore this topic, data were gathered via questionnaire, observations, and individual interviews on the beliefs and practices of Core French teachers in the Toronto, Ontario region. In analyzing the data through the lens of a hybrid framework of complexity theory and the theory of self-efficacy, small differences in how teachers handled chaos, the term used in complexity theory to describe periods of instability in non-linear systems such as Core French classrooms, were found to be a key factor in explaining discrepancies between beliefs and practices. Moreover, levels of self-efficacy were found to influence how teachers handled chaos. Findings also revealed important differences in outcome (e.g., teacher and student comfort with and use of the target language) in classes taught by teachers with a high degree of self-efficacy versus those with lower levels of self-efficacy.
This document is protected by copyright law. Use of the services of Érudit (including reproduction) is subject to its terms and conditions, which can be viewed online.

https://apropos.erudit.org/en/users/policy-on-use/ 


\title{
Understanding the Relationship Between Second Language Teacher Beliefs and Their Instructional Practices: A Case Study of Core French Teachers
}

\author{
Usha Viswanathan \\ Glendon College, York University
}

\begin{abstract}
This study explores the relationship between Core French teachers' beliefs and their instructional practices. In the literature, contextual elements, as well as the compatibility between teacher beliefs and second language teaching approaches such as communicative language teaching (CLT) have been regularly cited as key factors contributing to discrepancy between beliefs and practices. However, these factors did not adequately explain what I had witnessed as a teacher educator. To explore this topic, data were gathered via questionnaire, observations, and individual interviews on the beliefs and practices of Core French teachers in the Toronto, Ontario region. In analyzing the data through the lens of a hybrid framework of complexity theory and the theory of self-efficacy, small differences in how teachers handled chaos, the term used in complexity theory to describe periods of instability in nonlinear systems such as Core French classrooms, were found to be a key factor in explaining discrepancies between beliefs and practices. Moreover, levels of self-efficacy were found to influence how teachers handled chaos. Findings also revealed important differences in outcome (e.g., teacher and student comfort with and use of the target language) in classes taught by teachers with a high degree of self-efficacy versus those with lower levels of selfefficacy.
\end{abstract}

\section{Résumé}

Dans cette étude, le lien entre les croyances des enseignants de français langue seconde et leurs pratiques pédagogiques est exploré. En tant qu'ancienne formatrice d'enseignants de français langue seconde, une de mes préoccupations principales était d'aider mes étudiants à assurer une convergence entre leurs croyances et leurs pratiques. Afin d'explorer ce sujet, une recherche a été effectuée auprès d'enseignants de français langue seconde dans la région de Toronto. La recherche dans le domaine présente souvent l'argument que les croyances des enseignants les empêchent de progresser et d'adopter des pratiques pédagogiques nontraditionnelles telles qu'une approche communicative. Pourtant, ceci ne correspond pas à ce que j'ai observé en salle de classe. En analysant mes données à travers un cadre théorique hybride de la théorie de la complexité et la théorie de l'auto-efficacité, je démontre que c'est la capacité d'un enseignant de gérer des moments de chaos, terme pour désigner une période d'instabilité dans tout système non-linéaire tel que la classe de français langue seconde, qui joue un rôle déterminant. La capacité de gérer le chaos est influencée par le niveau d'autoefficacité de l'enseignant. Ceux qui ont un niveau d'auto-efficacité plus élevé réussissent à naviguer le chaos à ce que leurs pratiques restent fidèles à leurs croyances. 


\section{Understanding the Relationship Between Second Language Teacher Beliefs and Their Instructional Practices: A Case Study of Core French Teachers}

\section{Introduction}

In this article I explore the relationship between French as a second language (FSL) teachers' beliefs and their instructional practices. To address this topic, I completed a study of Core French teachers in public secondary schools in Ontario. I collected data on the beliefs and practices of Core French teachers in the Greater Toronto Area via an online questionnaire, in-class observations, and individual interviews. As a former FSL teacher educator, one of my most important preoccupations was the challenge faced by teacher candidates to enact practices aligned with their beliefs. In the literature, contextual elements, compatibility between teacher beliefs and second language teaching approaches such as communicative language teaching (CLT), and teacher understanding of these approaches have been cited as key factors in a teacher's ability to enact practices aligned with their beliefs. While these factors are all important, they do not adequately explain what I observed as an FSL teacher educator. As an FSL teacher educator, I observed that while my teacher candidates shared similar profiles, beliefs, and practices, some enacted practices aligned with their beliefs while others did not.

Furthering understanding of the relationship between beliefs and instructional practices is essential to ensuring teachers can enact practices aligned with their beliefs. It has been argued that complexity theory and the theory of self-efficacy provide a conceptual framework through which to better understand the relationship between teacher beliefs and their instructional practices. Complexity theory (Larsen-Freeman, 1997) stresses the importance of chaos - periods of uncertainty and instability inherent in all complex nonlinear systems, such as the second language classroom - and the sensitivity of these types of systems to the smallest of changes in initial conditions. A key factor in understanding the relationship between teacher beliefs and their instructional practices is the teacher's role in navigating periods of chaos in the classroom. Small differences in instructional practices to handle periods of chaos can lead to important differences in outcome (i.e., consistency or inconsistency between beliefs and practices). The ability to effectively handle chaos is influenced by a teacher's level of self-efficacy. Self-efficacy is the judgement of one's own abilities, specifically the ability to meet any challenges and to complete a task successfully (Bandura, 1977, 1982, 1986).

In this article I first provide an overview of the existing literature on Core French teachers' beliefs and their instructional practices. Second, I present the research questions I addressed in this study as well as the methodology I employed. Next, I explain complexity theory and the theory of self-efficacy, the two theories that ground the research. Fourth, I present the profiles of the wider pool of 47 participants and the 13 focal participants. This is followed by an analysis of data I collected via questionnaire on Core French teachers' beliefs about second language teaching and CLT, and their declared practices. I then present my analysis of the data collected on the 13 focal participants during classroom observations and individual interviews are analyzed. I analyze the former through the lens of complexity theory and the latter through the lens of the theory of self-efficacy. Finally, a case study of two Core French teachers through a combined lens of complexity theory and the theory of self-efficacy demonstrates how these two theories can provide a unifying framework for a better understanding of the relationship between teacher beliefs and 
practices. The article concludes with a summary of the contributions of the study, its limitations, implications for FSL teacher education, and suggestions for future research.

\section{The Literature on Teachers' Beliefs and Their Instructional Practices}

While numerous studies have found consistency between teachers' beliefs and practices (e.g., Richardson, Andres, Tidwell, \& Lloyd, 1991), an equal number of studies have found that teachers' practices do not always correlate with their beliefs (e.g., Basturkmen, 2012; Basturkmen, Loewen, \& Ellis, 2004). Navarro and Thornton (2011) and Basturkmen (2012) argued that contextual factors mediate teachers' ability to act in accordance with their beliefs. These constraints include lack of proper teaching materials, lack of support from administration and colleagues, and large class sizes. These factors explain why teachers' practices "sometimes contravene their stated beliefs" (Fang, 1996, p. 53). Gabillon (2012), Maestre and Gindidis (2016), and Pinnegar and Carter (1990) asserted that moral conflict between teachers' beliefs and second language teaching approaches such as CLT and the Common European Framework of Reference for Languages (CEFR) action-oriented approach, curriculum documents, other course materials, and evaluations contributes to inconsistency between beliefs and practices. Gabillon (2012) argued that teachers interpret, modify, and adjust instructional approaches, curriculum documents, and course materials to fit their beliefs. Manzano (2015) maintained that the implementation success of approaches such as CLT depends on the extent of a teacher's knowledge and understanding of CLT. Participants in Manzano's study claimed that they employed CLT; however, their beliefs and practices were found to be incompatible with CLT.

To my knowledge, no studies exist assessing the relationship between Core French teacher beliefs and their instructional practices. The literature specific to Core French is focused primarily on the context in which Core French teachers teach, assessing such things as: the amount of funding to Core French programs; the amount of administrative support for Core French teachers and Core French programs; student and parent attitudes toward French/Core French; class sizes; support for English language learners and special needs students in Core French programs; length of Core French teaching periods; and number of hours of instructional time (Lapkin, MacFarlane, \& Vandergrift, 2006; Lapkin, Mady, \& Arnott, 2009; Mollica, Phillips, \& Smith, 2005; Richards, 2002).

The few studies that do exist on teachers' instructional practices include one by Frolich, Spada, and Allen (1985), who assessed the degree to which teachers' instructional approaches and activities in Core French, Extended French, French Immersion, and English as a Second Language (ESL) programs were communicative in nature, using a framework they developed named Communicative Orientation of Language Teaching (COLT). They found that in Core French, teachers' instructional practices focused exclusively or primarily on form. Calman and Daniel (1998, as cited in Lapkin, Mady, \& Arnott, 2009) completed a study evaluating the types of instructional approaches and activities exclusively in Core French classrooms in Ontario. They identified two main issues: (a) the activities they observed were predominantly grammar-oriented, and (b) there was widespread use of English by teachers and students for classroom communication. More recent studies by Howard (2006) and Salvatori (2008) found that Canadian Core French teachers continue to focus on form and find it challenging to maintain French as the language of instruction. Other recent studies, by Faez, Majhanovich, Taylor, Smith, and Crowley (2011) and 
Rehner (2017), measured the impact of teacher training in the use of the CEFR and access to related materials on teacher beliefs and their instructional practices. Faez et al. found positive attitudinal changes amongst teachers provided with CEFR training and materials but this did not necessarily translate into change in classroom practice. Participants in Rehner's study stated that after having received CEFR training, they planned lessons much more on speaking and listening rather than on reading and writing; however, the study did not evaluate changes in actual classroom practice.

With regard to Core French teachers' beliefs about Core French teaching, a 2010 report by Majhanovich and Smith found that $70 \%$ of Core French teachers participating in a summer course in Quebec City felt most comfortable teaching the form of the language (i.e., grammar rules and pronunciation of vocabulary words). More importantly, while the teachers in the survey were most comfortable teaching grammar, they also indicated that grammar analysis was the "least valuable teaching practice" and they "seemed to indicate a strong belief in using a communicative approach" (Majhanovich \& Smith, 2010, p. 16). Amongst this same group of respondents, almost all admitted that they began teaching in French $100 \%$ of the time, but this had gradually declined to "as low as 35 to $50 \%$ " (Majhanovich \& Smith, 2010, p. 15) of the time over the years. Teachers in the study identified pressure from students to use less French, pressure from colleagues to use more English, the difficulty of explaining complex grammar rules in the target language (TL), and lack of confidence with their fluency as factors affecting the use of French in the Core French classroom.

Prior to analyzing Core French teacher beliefs and their instructional practices through a hybrid lens of complexity theory and the theory of self-efficacy, I provide an explanation of these two theories.

\section{Complexity Theory and the Theory of Self-Efficacy}

Complexity theory focuses on the behaviour of complex, non-linear systems. Complex, non-linear systems are systems involving many components. The behaviour of the whole system "arises from the interactions of its individual components" (LarsenFreeman, 1997, p. 142). Complexity theory emphasizes the inevitability of chaos-periods of instability and unpredictability - in all complex non-linear systems. In non-linear systems, "a slight change in initial conditions can have vast implications for future behaviour" (Larsen-Freeman, 1997, p. 144). This phenomenon was first observed by a meteorologist named Lorenz (1963). In running computerized equations to model and predict weather conditions, Lorenz entered the rounded figure of .506 instead of his original figure of .506127. Because Lorenz considered the two figures to be almost the same, he expected the model to yield similar results. Yet Lorenz ended up with radically different outcomes. Lorenz concluded: "two states differing by imperceptible amounts may eventually evolve into two considerably different states" (p. 133). He coined the term butterfly effect to explain this situation; tiny differences in input can quickly become overwhelming differences in output (Gleick, 1987). In other words, two non-linear systems - no matter how similar their initial conditions - with the slightest difference in input will diverge exponentially over time (Larsen-Freeman, 1997).

The Core French classroom can be viewed as a complex non-linear system with the teacher and students as key components within the system. Periods of chaos (instability and uncertainty) are inevitable as complex non-linear systems are extremely sensitive to 
changes in initial conditions. Complexity theory allows for a better understanding of how teachers starting with what appear to be similar input/initial conditions (i.e., the same grade/program, curriculum, textbook, student profiles, class size, beliefs, and practices) can diverge exponentially over time in terms of output/outcome (e.g., teacher and student use of and comfort with the TL). Complexity theory posits that when a Core French teacher employs an instructional practice, initial conditions are almost inevitably disrupted and some form of chaos ensues. Teachers must deal with periods of chaos not knowing exactly what form they will take and how long they will last. Discomfort with chaos (i.e., uncertainty and instability) is what may prevent and/or discourage teachers from introducing and following through with a new instructional practice. Teachers' navigation of the period of chaos can have a significant impact on the relationship between their beliefs and practices. Seemingly small or insignificant differences in teacher practices in the end can matter a great deal. They can have a huge impact on the outcome, as Lorenz (1963) discovered with his meteorological figures. While complexity theory can provide insight into why teachers with similar beliefs and instructional practices can end up with significant differences in output/outcome, the theory of self-efficacy can enable a better understanding of the factors affecting how a teacher handles periods of chaos, notably whether a teacher follows through with an instructional practice.

Bandura (1997) defined perceived self-efficacy as beliefs in one's capabilities to organize and execute the courses of action required to produce given attainments. Knowledge, which includes skill and level of competence, is an inadequate predictor of future behaviour and action, as it is "mediated by a person's belief in their abilities to put the acquired skills to use" (Siwatu, 2007, p. 1088). Bandura (1997) further affirmed that "people's level of motivation, affective states, and actions are based more on what they believe than on what is objectively true" (p. 2). In other words, a person's behaviour is more a product of what they believe they can accomplish than of their actual ability.

According to Bandura (1986), individuals with high levels of self-efficacy believe that they can achieve their objectives even in the face of adversity. Those with low levels of selfefficacy are more likely to doubt their ability to achieve a certain level of performance. They may also feel a sense of uncertainty and insecurity, and are more likely to give up in the face of adversity.

In the specific case of Core French teachers, the teachers' judgements of their ability to introduce a new approach or activity successfully, the effectiveness of the Core French program, the success or lack of success of an activity, and students' abilities and levels of motivation are important predicators of their behaviour during periods of chaos. Core French teachers with a high degree of self-efficacy about their Core French teaching are more likely to judge themselves able to introduce a new approach successfully, to believe in the effectiveness of the Core French program, and to believe that their students are motivated and able to handle a new approach or activity. They are more likely persevere in the face of chaos and thus achieve outcomes/enact practices consistent with their beliefs, while those with a low degree of self-efficacy about their Core French teaching are less likely to persevere in the face of chaos (they are more likely to modify or reverse course) and as a result achieve outcomes/enact practices that are less consistent or altogether inconsistent with their beliefs.

Bandura (2006) asserted that individuals with a high degree of self-efficacy possess the following characteristics: strong levels of perseverance; confidence in their ability to affect environmental conditions and exercise control over their environment; and high 
levels of commitment, effort, and resilience in the face of adversity. Gibson and Dembo (1984) and Podell and Soodak (1993) associated higher levels of teacher self-efficacy with greater teacher effort and persistence when things do not go smoothly. Guskey (1988) argued that those with higher levels of self-efficacy display greater openness to new ideas and willingness to experiment. Allinder (1994) found that teachers with high self-efficacy exhibit greater enthusiasm for teaching. Burley, Hall, Villeme, and Brockmeier (1991) along with Glickman and Tamashiro (1982) found that teachers with a high degree of selfefficacy were more likely to stay in teaching.

Bandura (1977, 1982, 1986) also argued that levels of self-efficacy are the result of enactive experiences, vicarious experiences, and verbal persuasion. A positive enactive experience - the successful completion of a task - can powerfully reinforce a person's sense of self-efficacy. A negative enactive experience-failure to complete a task - can undermine a person's sense of self-efficacy (Tschannen-Moran \& Woolfolk Hoy, 2001). Vicarious experiences, as termed by Bandura $(1977,1982,1986)$, also contribute to increases and decreases in self-efficacy. That is, when individuals observe the successful completion of a task by other people like themselves, this can increase their sense of selfefficacy (Bandura, 1982). Similarly, observing people of similar competence fail can lower observers' perceptions of their abilities. Verbal persuasion can also influence levels of selfefficacy. Verbal persuasion is employed to encourage people to believe that they possess the capabilities necessary to be successful at a given activity or task (Bandura, 1982). A person who receives positive verbal reinforcement to attempt a task is more likely to attempt that task, to put forth greater effort into the task, and to sustain the effort (Tschannen-Moran \& Woolfolk Hoy, 2001).

Self-efficacy beliefs arguably vary depending on the context and specificity of tasks. In the context of schools, teacher self-efficacy beliefs can be defined as teachers' individual beliefs in their capabilities to perform specific teaching tasks at a specified level of quality in a specified situation (Dellinger, Bobbett, Olivier, \& Ellet, 2008). Chacon (2005) argued that a teacher's level of self-efficacy influences their perceptions of the consequences of choosing certain instructional practices and thus affects their choice of instructional practices. In a study by Chacon, teachers who were confident about their abilities and enjoyed their teaching were more willing to implement new and innovative practices.

The next section of the paper introduces the research questions addressed in this paper.

\section{Research Questions}

In this study I explored the following primary research questions:

1. What is the relationship between Core French teachers' beliefs and their instructional practices?

2. What factors affect the relationship between Core French teachers' beliefs and their instructional practices? 
To answer the two primary research questions above, I explored five secondary questions:

1. What is the profile of the participants in the study?

2. What are participants' beliefs about second language teaching, Core French programs, and communicative language teaching (CLT)?

3 . What are their declared practices?

4. How do the actual practices of participants compare with their declared practices?

5. What are participants' perceptions/impressions of their practices and how does this affect their instructional practices?

The next section outlines the methodology employed to gather and analyze the data.

\section{Methodology}

To collect and analyze the data I employed a mixed-method approach, using both quantitative and qualitative methods (Creswell \& Plano Clarke, 2011; Greene, 2007). I sent out a link to an online questionnaire to approximately 100 Core French teachers (Viswanathan, 2016). A wider participant pool of 48 teachers completed the questionnaire on beliefs and instructional practices. At the end of the questionnaire, I asked focal participants if they would be willing to participate in the classroom observation and individual interview phases of the research. A focal participant pool of 13 teachers consented (nine teachers in their first 5 years of Core French teaching and four teachers with 5-10 years' experience).

The questionnaire was for the purposes of collecting data on Core French teacher beliefs about second language teaching, the Core French program, CLT, and their declared instruction practices. The questionnaire consisted of a combination of ranking, multiplechoice, and checklist questions. I developed a set of multiple choice questions to collect information about participants' FSL backgrounds, including number of years teaching, the FSL program participants had completed as students, and their FSL teaching qualifications. I employed a rating scale to determine the frequency of use of different types of instructional practices, including focus/content of the lesson, amount of teacher versus student-centred instruction, use of the TL (French), and use of pedagogical versus nonpedagogical materials. Another rating scale gauged teachers' opinions about what constitutes CLT and the difficulties and challenges involved in adopting CLT in Core French classrooms. Participants were asked to identify the level of truth of several statements regarding CLT and the level of significance of a series of challenges to adopting CLT (Dörnyei, 2003).

I conducted classroom observations over a period of 3 months to collect data on Core French teachers' actual instructional practices. Each teacher was observed for two to nine classes, with each class lasting from 40-75 minutes. I took hand-written notes on what the teachers and the students said and did. The notes also included information on nonverbal communication and the types of materials and activities being used. Semi-structured individual interviews (Viswanathan, 2016) followed the in-class observations to help me gain insight into focal participants' judgements of the observed lessons. Each interview lasted approximately 1 hour and was audio-recorded and then transcribed. 
I analyzed the quantitative data collected via questionnaire using SPSS software, assessing for frequency distribution. To analyze the qualitative data - the hand-written observation notes and the transcribed individual interviews - I used NVivo software. I organized the data into coding categories. The coding categories for the observation notes were derived from the questionnaire, while the coding categories to organize the data from the individual interviews were developed based on the characteristics of individuals with high and low self-efficacy identified by Bandura (2006).

Prior to presenting a summary of the analyses of the questionnaire, observation, and interview data, I now present the profiles of the wider pool of 47 participants and the 13 focal participants.

\section{Participants' Profiles}

The profile of both the wider pool of participants and the focal participants in this study mirrors the profiles reported in other Core French studies (e.g., Lapkin, MacFarlane, \& Vandergrift, 2006). All the teachers who participated in this study were teaching in Ontario. ${ }^{1}$ Of these participants, $80 \%$ were women. Their first or dominant language was English, and they had learned French as a second language. Most completed their schooling in Ontario in a Core French or French Immersion program (public). The participants were similar in the following ways: teaching status (primarily full-time); teaching load (mostly Grades 9 and 10 Core French); method or approach exposed to as students (Core French students identified grammar translation and French Immersion students identified immersion as a method); and university programs completed (major or minor in French studies, 1-year B.Ed.). All participating teachers had completed a specialization/qualification in FSL, which is a requirement to teach FSL at all levels in Ontario. Regarding number of years of teaching experience, 10 of $13(77 \%)$ focal participants were in their first 5 years of teaching with six $(50 \%)$ in their first 2 years. This contrasts with the wider participant pool. One-third (14) were in their first 2 years, onethird (15) in their first 5 years, and one-third (14) had taught for at least 10 years.

Table 1 contains an overview of the profiles of the 13 focal participants. I gave each participant a pseudonym to protect their anonymity. Ten of the 13 focal participants were female. Nine had been teaching for less than 5 years. For most focal participants (11), English was their first or dominant language and they had learned French as a second language. Six were enrolled in a Core French program as students, while five were in French Immersion. Two attended French first language schools. All but Pauline were teaching in a public school. Ten held full-time permanent positions, while three were fulltime on a temporary contract. Nine of thirteen taught at least one section of Grade 9 Core French. 
Table 1

Overview of Focal Participants

\begin{tabular}{|c|c|c|c|c|c|c|}
\hline Pseudonym & $\begin{array}{l}\text { Male (M) } \\
\text { or Female } \\
\text { (F) }\end{array}$ & $\begin{array}{l}\text { Years of FSL } \\
\text { teaching } \\
\text { experience }\end{array}$ & $\begin{array}{l}\text { Program } \\
\text { completed as } \\
\text { student }\end{array}$ & FSL qualification & $\begin{array}{l}\text { Teaching } \\
\text { status }\end{array}$ & Teaching context \\
\hline Zara & $\mathrm{F}$ & 1 & Core & 1-year B.Ed. & $\begin{array}{l}\text { Full-time } \\
\text { LTO }\end{array}$ & $\begin{array}{l}\text { Core French } \\
\text { Grade } 9 \text { (Applied, } \\
\text { Academic) }\end{array}$ \\
\hline Max & M & 10 & $\begin{array}{l}\text { French first } \\
\text { language }\end{array}$ & 1-year B.Ed. & Full-time & $\begin{array}{l}\text { Core French } \\
\text { Grade } 9 \text { (Applied, } \\
\text { Academic) }\end{array}$ \\
\hline Maria & $\mathrm{F}$ & 2 & Core & $\begin{array}{l}\text { Additional } \\
\text { Qualification }\end{array}$ & $\begin{array}{l}\text { Full-time } \\
\text { LTO }\end{array}$ & $\begin{array}{l}\text { Core French } \\
\text { Grade } 9 \\
\text { (Beginner, } \\
\text { Applied, } \\
\text { Academic) }\end{array}$ \\
\hline Will & M & 2 & Immersion & 1-year B.Ed. & Full-time & $\begin{array}{l}\text { Core French } \\
\text { Grades 9, 10, } 11 \\
\text { (Applied, } \\
\text { Academic, IB) }\end{array}$ \\
\hline Pauline & $\mathrm{F}$ & 1 & $\begin{array}{l}\text { French first } \\
\text { language }\end{array}$ & 1-year B.Ed. & Full-time & $\begin{array}{l}\text { Core French } \\
\text { Grades 7, 8, } 9 \\
\text { (Academic) }\end{array}$ \\
\hline Faizal & M & 5 & $\begin{array}{l}\text { FSL } \\
\text { (out of } \\
\text { country) }\end{array}$ & 1-year B.Ed. & Full-time & $\begin{array}{l}\text { Core French } \\
\text { Grades } 7,8\end{array}$ \\
\hline Brenda & $\mathrm{F}$ & 1 & Core & 1-year B.Ed. & Full-time & $\begin{array}{l}\text { Core French } \\
\text { Grade } 9 \text { and } 10 \\
\text { (Applied, } \\
\text { Academic) }\end{array}$ \\
\hline Fabia & $\mathrm{F}$ & 10 & Core & 1-year B.Ed. & Full-time & $\begin{array}{l}\text { Core French } \\
\text { Grades } 7,8\end{array}$ \\
\hline Phyllis & $\mathrm{F}$ & 3 & Core & 1-year B.Ed. & Full-time & $\begin{array}{l}\text { Core French } \\
\text { Grade } 9 \text { and } 10 \\
\text { (Applied, } \\
\text { Academic) }\end{array}$ \\
\hline Mary & $\mathrm{F}$ & 1 & Immersion & 1-year B.Ed. & $\begin{array}{l}\text { Full-time } \\
\text { LTO }\end{array}$ & $\begin{array}{l}\text { Core French } \\
\text { Grades } 11,12\end{array}$ \\
\hline Francis & $\mathrm{F}$ & 3 & Immersion & 1-year B.Ed. & Full-time & $\begin{array}{l}\text { Core French } \\
\text { Grade } 9 \text { and } 10 \\
\text { (Applied, } \\
\text { Academic) }\end{array}$ \\
\hline Marina & $\mathrm{F}$ & 2 & Immersion & 1-year B.Ed. & Full-time & $\begin{array}{l}\text { Core French, } \\
\text { Grades } 11 \text { and 12, } \\
\text { Grade } 9 \\
\text { Immersion }\end{array}$ \\
\hline Page & $\mathrm{F}$ & 10 & $\begin{array}{l}\text { FSL (out of } \\
\text { province) }\end{array}$ & $\begin{array}{l}\text { Concurrent } \\
\text { program }\end{array}$ & Full-time & $\begin{array}{l}\text { Core French } \\
\text { Grade } 9 \\
\text { Academic }\end{array}$ \\
\hline
\end{tabular}

Note. $\mathrm{FSL}=$ French as a second language; $\mathrm{LTO}=$ long term occasional contract; $\mathrm{IB}=$ International Baccalaureate. 
In the following section I analyze the results of the questionnaire, including participants' beliefs about second language teaching and CLT as well as their declared instructional practices.

\section{Analysis}

\section{Participants' Beliefs About Second Language Teaching}

In the questionnaire, teachers were asked whether they agreed or disagreed with a list of statements about second language teaching and learning. This was done to determine whether teachers' beliefs were compatible with non-traditional second language teaching approaches such as CLT. As in Graden (1996), the participants in this study, both the wider participant pool and the focal participant pool, shared similar beliefs about second language teaching and learning. As in the study by Majhanovich and Smith (2010), teacher beliefs were found to be compatible with CLT. For example, $100 \%$ of focal participants and $98 \%$ of the wider participant pool strongly agreed or agreed that the focus of second language instruction should be on listening and speaking. One hundred percent of focal participants and the wider participant pool either strongly agreed or agreed that large amounts of TL input were essential to learning a second language. One hundred percent of focal participants and $79 \%$ of all participants strongly agreed or agreed that student interaction in the TL was crucial. In the case of the statement, "learning about the TL culture is essential to learning the language," $92 \%$ of focal participants and $87 \%$ of the wider participant pool strongly agreed or agreed.

\section{Participants' Views on CLT}

Participants were asked whether they believed the following statements about CLT to be completely true, somewhat true, or not true. The statements were:

- CLT focuses mostly on oral communication/interaction in the TL (French)

- CLT involves no explicit teaching of grammar rules

- CLT involves a lot of role-playing

- CLT requires the teacher to have a high degree of proficiency in French

- CLT requires greater knowledge of the TL culture(s), and

- CLT relies heavily on the use of authentic materials.

Ninety percent of focal participants and the wider participant pool believed each of the above statements to be completely true or somewhat true.

Next, they were asked about contextual challenges in adopting CLT in Core French classrooms in Ontario. Participants were encouraged to indicate the level of significance of teacher-related challenges such as lack of teacher proficiency in the TL, lack of teacher knowledge of the TL culture, lack of availability of appropriate materials and resources, and lack of teacher training. Over $90 \%$ of respondents from both the focal participant group and the wider participant pool indicated that the above represented very significant or significant challenges. 
Participants were queried about how significant the following student-related difficulties were:

- inadequate student level of proficiency in the TL

- student discomfort with the approach (interactive speaking activities)

- student preference for teacher-centered instruction and instruction and activities focusing on form, and

- students unused to taking risks and fearful of making mistakes in the TL.

Student-related difficulties appeared to pose a less significant barrier. Fifty-eight percent of focal participants and $66 \%$ of the wider participant pool identified Core French students' fear of taking risks and students' fear of making mistakes as a very significant challenge. Students used to teacher-centered instruction was a very significant obstacle for $58 \%$ of focal participants and $51 \%$ of the wider participant pool, while discomfort with communicative activities was viewed as a very significant obstacle by $50 \%$ of focal participants and $53 \%$ of the wider participant pool. Thirty-three percent of focal participants and $43 \%$ of all participants identified lack of student TL proficiency as a very significant challenge while $33 \%$ of focal participants and $28 \%$ of the wider participant pool identified student preference for instruction focused on form as a very significant challenge.

Teachers were asked in the questionnaire about systemic challenges in adopting CLT:

- lack of support from administration and/or colleagues

- curriculum and departmental expectations incompatible with CLT

- class sizes too large, and

- class composition too diverse.

Systemic difficulties appear to pose the fewest obstacles. Amongst focal participants, the biggest challenge was the curriculum. Fifty-eight percent of focal participants felt that the FSL curriculum represented a very significant obstacle to adoption of CLT. However, it is important to note that a new more explicitly communicative/actionoriented curriculum was released in Ontario in 2014. Mandatory implementation began in September of 2015. Amongst the wider participant pool, lack of funds to purchase materials was identified as the biggest obstacle (55\%). Lack of support from administration was the least problematic, particularly for focal participants. Only forty percent of focal participants felt lack of support from administration posed a significant barrier.

For teachers in this study, much like in the literature, certain contextual factors exerted a powerful influence on a teacher's ability to put into practice CLT. Participants identified numerous contextual factors - particularly teacher-related — impeding the adoption of CLT; nevertheless, they remained very enthusiastic to adopt CLT. Many indicated that they had already attempted or were attempting to do so. Participating teachers were asked whether they presently employed some aspect of CLT in their Core French classrooms. Over $90 \%$ of focal participants and the wider participant pool responded yes to this question. Teachers who employed (or had employed) CLT were further asked about their satisfaction with the results. Amongst those teachers who employed or had employed CLT, satisfaction was over $90 \%$. Regarding whether they intended to employ CLT in the 
future, $92 \%$ of focal participants and a resounding $98 \%$ of the wider participant pool (all except one teacher) intended to use the approach in future.

\section{Participants' Declared Practices}

Once again, consistent with the results reported in Majhanovich and Smith (2010), $57 \%$ of focal participants and $65 \%$ of the wider participant pool in this study declared that their lessons were always or often focused on a grammatical concept. Focal participants $(92 \%)$ and the wider participant pool (94\%) declared that their classes were mostly teachercentered and that they always or often made use of textbooks/workbooks. Both groups identified that they most frequently used French for expressing routine words and phrases (e.g., Bonjour, Au revoir, Comment allez-vous?) and engaging in simple teacher-led question-answer drill-type activities (i.e., teacher asks prepared questions and students provide short answers) but were far less likely to employ French when introducing a new concept - particularly a grammar concept - explaining or reviewing for a test, and speaking to individual or small groups of students. Only $17 \%$ of focal participants and $15 \%$ of all participants declared that they always spoke French with individuals and small groups of students.

Below is a discussion of focal participants' actual instructional practices, taken from data collected during classroom observations.

\section{Participants' Actual Practices}

I observed each focal participant for one to three days to determine the focal participants' actual practices. In total, I observed as 13 teachers taught 42 Core French lessons in a variety of Core French settings (Grades 7 to 12). I analyzed the lessons to determine the focus of instruction, the center of instruction (i.e., teacher-centered versus student-centered), teacher use of the TL, types of testing tools, kinds of resources employed by the teacher, and types of speaking, comprehension, and writing activities. For each category, I calculated the number of references or occurrences and the number of teachers.

Most classes I observed, regardless of the teacher, grade, and school, were focused on a grammatical concept. Almost $60 \%$ of observed lessons or 28 of 42 lessons were focused all or in part on form. This was particularly the case in the Grade 9 and 10 Core French classes regardless of stream (i.e., academic, applied, beginner). Teacher-centered instruction dominated in terms of minutes/percentage ( $51 \%$ of observed lessons); however, a significant amount of pair and group work did take place (33\% of observed lessons).

I found the greatest number of instances $(65 \%)$ of TL use by focal participants was in highly structured, closed-ended situations (i.e., communication involving one word or a short phrase) to communicate routine phrases to students and when engaging in drill-type activities with them. All 13 focal participants primarily or exclusively employed the TL to communicate routine phrases to students. Examples of routine phrases include: Levez-vous; Levez la main s'il vous plait; Silence s'il vous plait, Asseyez-vous, Je vais prendre les présences; Dans vos livres, tournez à la page 100; Ecoutez s'il vous plait. This was also the case with drill-type activities. Drill-type activities included simple questions asked by the teacher about student preferences, what students did or were planning to do over the weekend or during the holidays, or around pictures or a dialogue or story in a textbook/workbook/audio recording. There were fewer teachers (nine of 13) and fewer 
instances of TL use in more open-ended situations such as introducing a grammatical concept, presenting a new chapter in the textbook, explaining how to complete an exercise or activity, and discussing or correcting homework.

Overall, I found participants' actual classroom practices to be consistent with their declared practices, as well as with what has been reported in the literature. Previous studies of Core French teachers' practices by Calman and Daniel (1998), Frolich, Spada, and Allen (1985), Howard (2006), Lapkin, Mady, and Arnott (2009), and Salvatori (2008) all concluded that Core French instruction was largely teacher-centered and form-focused (grammar). In the case of this study, a large percentage of instructional time was spent on form: grammar exercises were the most common classroom activity and the centre of instruction was primarily the teacher. Nevertheless, there were several instances of pair and group work and interactive speaking activities. Teachers primarily made use of pedagogical materials, notably textbooks and workbooks approved by the Ministry of Education.

As noted earlier, Calman and Daniel (1998), Howard (2006), and Salvatori (2008) cited the widespread use of English by teachers and students for classroom communication. Levine (2003) found that use of the TL in second language classrooms was most often for topic- or theme-based communication and much less often for communication about grammar, tests, and assignments. In this study, TL use was most prevalent by teachers in highly-structured situations such as when expressing routine phrases and engaging in drilltype simple question-answer activities. The use of English was more prevalent in unstructured situations such as class discussions, introduction of a new concept, discussion of an upcoming test, and teacher interaction with individuals and small groups of students.

While in the questionnaire participants were found to share very similar beliefs and instructional practices, a more detailed analysis of the classroom observation notes revealed small differences in teacher techniques to provide comprehensible input and to promote student TL use in the Core French classroom. In the following section of the paper I discuss these small differences.

Techniques to provide comprehensible input. Focal participants employed a variety of techniques to provide comprehensible input, such as translation (of individual words or entire passages), codeswitching (alternating between English and French), repetition (of words or phrases), visual aids, gestures, intonation, multiple choice questions, and "or" questions. Table 2 contains observed instances of the above techniques for each focal participant. Although the number of scheduled classes I observed for each focal participant differed, the data provides interesting insight into the techniques employed by each teacher.

Most interesting is that Maria, Faizal, and Phyllis all made significant use of gestures, visual aids, and intonation. Faizal also frequently used "or" questions. The large number of observed use of gestures and "or" questions in the case of Faizal are the result of his use of the Accelerated Integrative Methodology (AIM) approach². Gestures and "or" questions are an integral part of the AIM approach, which he employed with his Core French classes. While far fewer instances of gestures, visual aids, intonation, multiple choice, and "or" questions were recorded for the remaining participants, it is notable that Will, Fabia, Pauline, Francis, and Page relied much more on gestures, visual aids, and intonation than on the use of translation to provide comprehensible input in the TL. Francis and Page did not in fact make use of any translation techniques. Meanwhile, the opposite was true for Mary, Brenda, and Zara, who relied primarily on translation techniques to 
provide comprehensible input. It should be noted that I did not observe Marina employ any techniques whatsoever; however, the only classes I observed her teach were two Grade 11 Core French classes, which she taught exclusively in French.

Techniques to encourage student target language use. As stated above, although I did not observe focal participants for the same number of periods, patterns did emerge in terms of their use of techniques to encourage students to employ the TL. Maria was responsible for eight of the 23 such recorded instances, Phyllis for six, Pauline for four, and Faizal for three. Meanwhile, in the case of Mary, Francis, Marina, Zara, Max, and Brenda, I observed no instances of the teacher explicitly encouraging the students to speak in French (refer to Table 3). Examples of such techniques included teachers saying to students: "En français s'il vous plait," "Pardon, je ne comprends pas," and "Répétez en français s'il vous plait" when a student spoke in English. Faizal started every class with students singing the AIM song, which begins with the sentence: "Maintenant, on parle français!" Fabia had even invented her own small rhyme to encourage students to speak French: "Si tu parles en français c'est bon ... Si c'est anglais c'est non."

What I will demonstrate in the next section is that these seemingly small differences in teacher techniques to provide comprehensible input (i.e., translation to English versus use of gestures, visual aids, intonation, multiple-choice, and "or" questions) and to promote student TL use in the Core French classroom resulted in considerable differences in output/outcome (i.e., teacher and student behaviours/responses in respect of the TL). As I noted earlier, this is termed the butterfly effect in complexity theory. 
Table 2

Observed Instances of Different Techniques Employed to Provide Comprehensible Input (by Focal Participant)

\begin{tabular}{|c|c|c|c|c|c|c|c|c|c|}
\hline Participant & $\begin{array}{l}\text { Code- } \\
\text { Switching }\end{array}$ & $\begin{array}{l}\text { Translation of } \\
\text { individual } \\
\text { words or } \\
\text { expressions }\end{array}$ & $\begin{array}{l}\text { Translation } \\
\text { of full } \\
\text { sentences } \\
\text { passages }\end{array}$ & $\begin{array}{l}\text { Use of } \\
\text { repetition }\end{array}$ & $\begin{array}{l}\text { Use of } \\
\text { visuals }\end{array}$ & $\begin{array}{l}\text { Use of } \\
\text { gestures }\end{array}$ & $\begin{array}{l}\text { Use of } \\
\text { intonation }\end{array}$ & $\begin{array}{l}\text { Use of } \\
\text { multiple } \\
\text { choice } \\
\text { questions }\end{array}$ & $\begin{array}{l}\text { Use of "or" } \\
\text { questions }\end{array}$ \\
\hline Faizal & 0 & 1 & 0 & 2 & 8 & 14 & 8 & 0 & 7 \\
\hline Fabia & 2 & 2 & 3 & 2 & 1 & 2 & 6 & 0 & 0 \\
\hline Mary & 8 & 1 & 12 & 0 & 0 & 2 & 3 & 0 & 0 \\
\hline Francis & 0 & 0 & 0 & 1 & 2 & 6 & 1 & 0 & 0 \\
\hline Marina & 0 & 0 & 0 & 0 & 0 & 0 & 0 & 0 & 0 \\
\hline Page & 0 & 0 & 0 & 3 & 1 & 3 & 3 & 0 & 2 \\
\hline Zara & 4 & 6 & 5 & 1 & 0 & 0 & 0 & 0 & 3 \\
\hline Max & 3 & 2 & 1 & 0 & 0 & 3 & 2 & 0 & 1 \\
\hline Maria & 26 & 12 & 4 & 3 & 4 & 17 & 7 & 2 & 2 \\
\hline Will & 2 & 4 & 2 & 1 & 3 & 9 & 0 & 1 & 0 \\
\hline Pauline & 5 & 2 & 2 & 0 & 0 & 0 & 7 & 0 & 0 \\
\hline Brenda & 25 & 9 & 6 & 0 & 1 & 2 & 0 & 0 & 0 \\
\hline Phyllis & 9 & 20 & 8 & 0 & 4 & 12 & 9 & 1 & 0 \\
\hline
\end{tabular}


Table 3

Number of Instances of Participants Explicitly Encouraging Students to speak French Number of recorded instances of teacher explicitly encouraging students to speak Teacher French

\begin{tabular}{ll} 
Feacher & French \\
Fabia & 2 \\
Mary & 0 \\
Francis & 0 \\
Marina & 0 \\
Page & 2 \\
Zara & 0 \\
Max & 0 \\
Maria & 8 \\
Will & 1 \\
Pauline & 4 \\
Brenda & 0 \\
Phyllis & 6 \\
\hline
\end{tabular}

\section{Important Differences in Output/Outcome}

Teacher target language use. Employing techniques other than French-English translation to provide comprehensible input appears to have a disproportionate impact on output/outcome (i.e., the amount of teacher and student use of French). Comparisons of TL use revealed that focal participants employed either large amounts of the TL or very little, with few participants falling in the middle. The amount of TL employed by each of the 13 participants is shown in Figure 1. Teachers who used techniques other than translation of full sentences and passages were the teachers who spoke the most French with their students. Zara, Mary, and Brenda, who relied primarily on translation, were amongst the focal participants who spoke the least French with their students. The same held true for use of techniques to encourage students to communicate in the TL. 


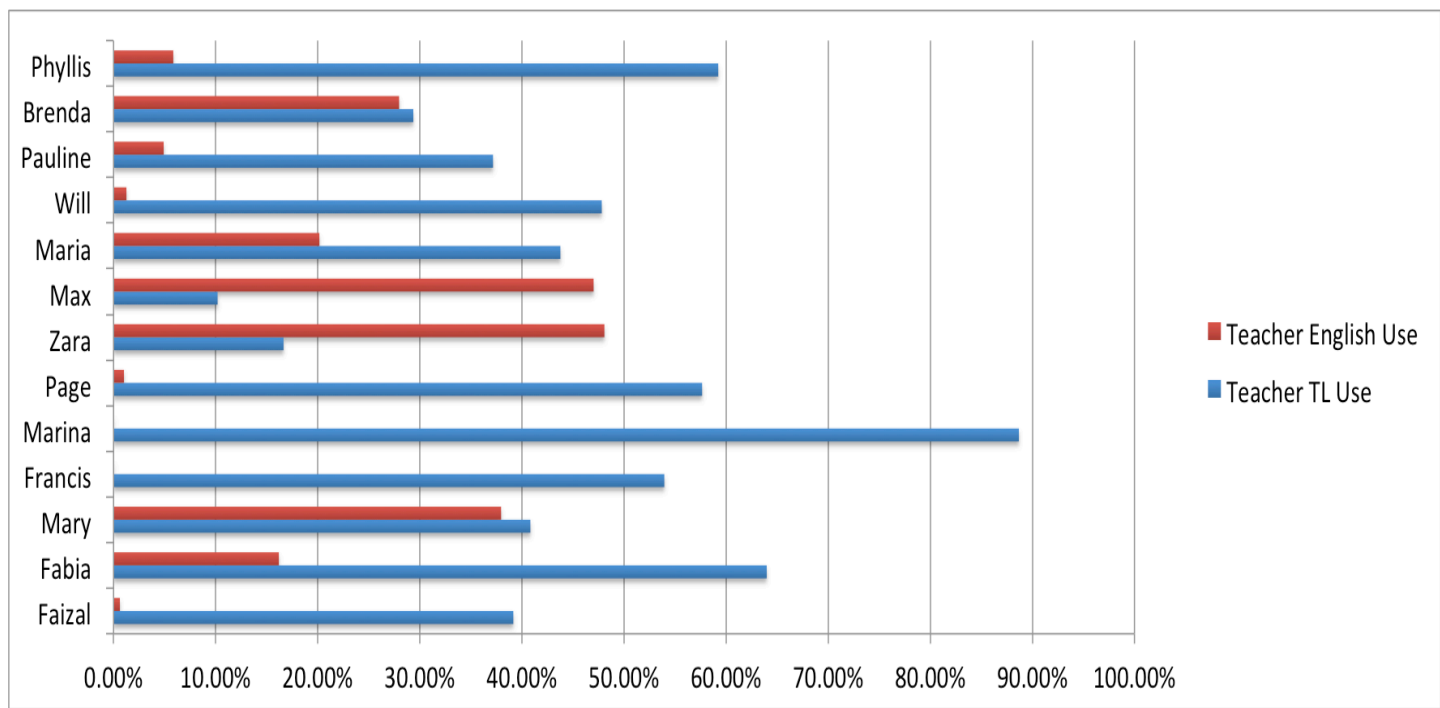

Figure 1. Teacher target language (TL, French) use versus first language (L1, English), indicated in percent of instructional time. ${ }^{3}$

I also found that teachers who employed large amounts of the TL did so regardless of grade (i.e., 7, 8, 9, 10, 11, or 12) and program (i.e., academic, applied, beginner, or university, see Figure 2). For example, Frances exclusively employed French with her Grade 9 applied and Grade 10 academic classes. Phyllis employed large amounts of the TL with all three of her classes: Grade 9 applied, Grade 9 academic, and Grade 10 academic. Meanwhile, Mary, Brenda, Max, and Zara employed more English than French with all their Core French classes.

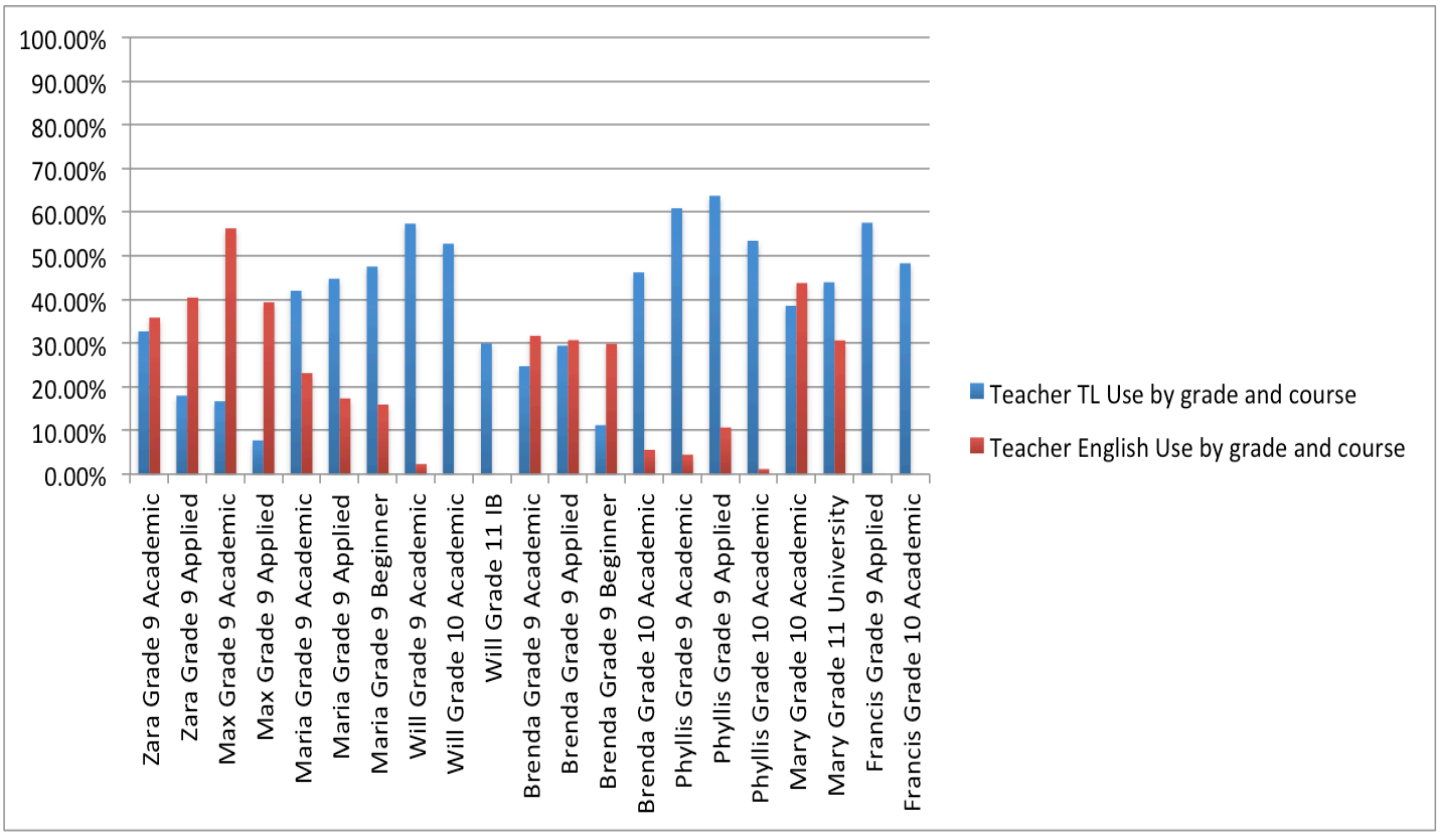

Figure 2. Teacher target language (TL, French) use versus first language (L1, English) use by grade and Core French course, indicated in percent of instructional time. 
Student target language use. The percentage of class time students spoke in the TL was also far higher in classes taught by teachers who used techniques other than translation to provide comprehensible input and who explicitly encouraged their students to speak French (Figure 3). Use of the TL by students was lowest in classes taught by Mary, Max, Zara, and Brenda - teachers who relied primarily on translation to provide comprehensible input and teachers who did not explicitly encourage their students to employ the TL. Student use of French was also found to be very teacher-dependent. That is, the percentage of class time students spoke in the TL was far higher in classes taught by teachers who themselves spoke large amounts of French. TL use by students was lowest in classes where teachers spoke the least French with their students. In other words, when the teacher employed the TL, students tended to employ the TL as well and when the teacher spoke English, students spoke English.

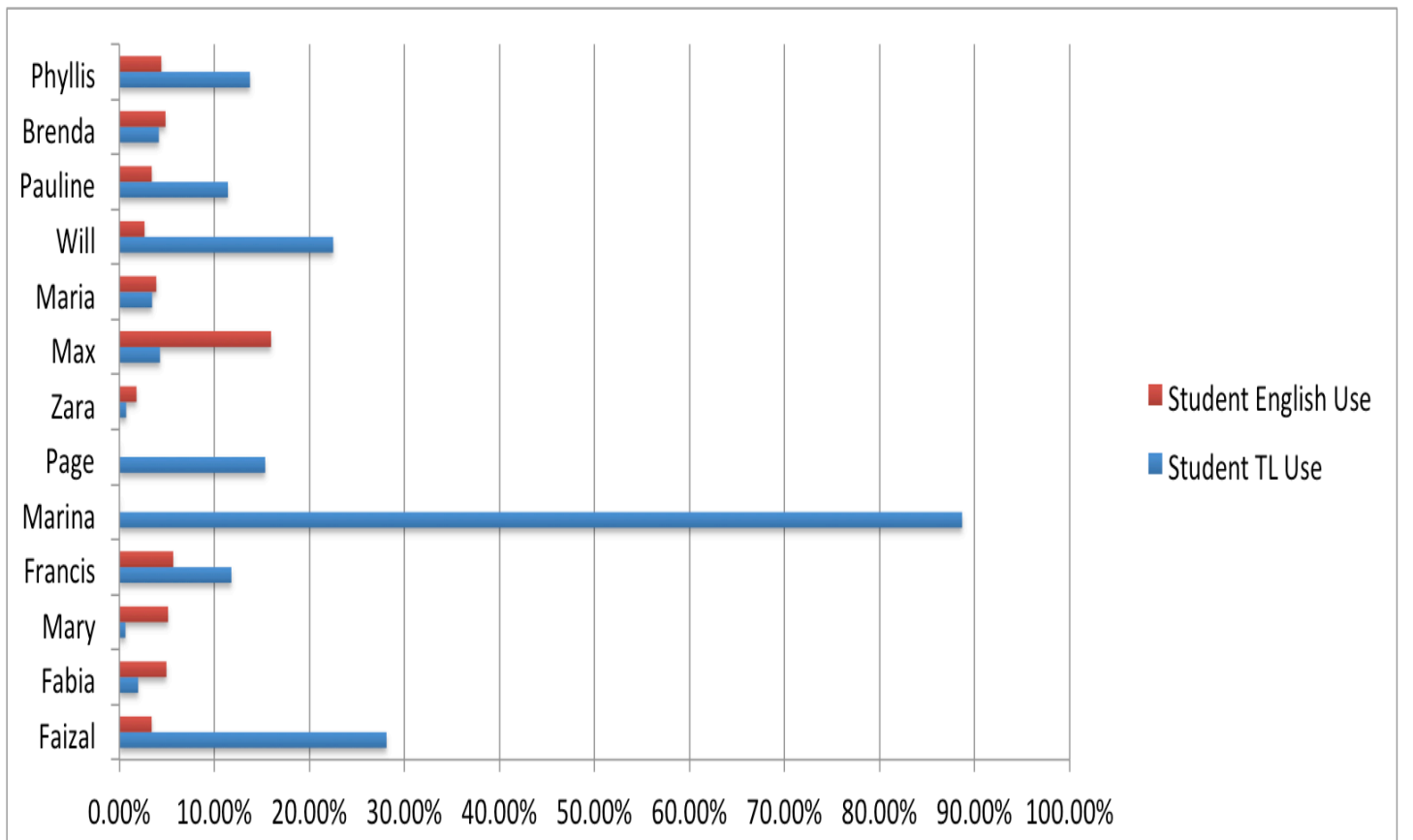

Figure 3. Student target language (TL, French) use versus first language (L1, English) use, indicated in percent of instructional time.

Student level of comfort with and understanding of the target language. In classes where the teacher regularly spoke French and employed techniques other than translation to provide comprehensible input, students demonstrated comfort with and understanding of the TL. Students were seen to be comfortable as they responded quickly without hesitation when spoken to in French; they did not ask the teacher to repeat what was said or to translate into English. Excerpts from Grade 9 and 10 classes taught by Phyllis and Francis demonstrate this point in both academic and applied settings (Table 4). Students did not necessarily respond in French; however, their responses/reactions demonstrated that they understood the teacher and were comfortable with the teacher speaking French. For example, Phyllis asked her Grade 9 applied students, "Où est Casper? Absent?" A student responded, "He's photocopying." Francis asked her Grade 10 students to put their bags on the chairs: "Sac sur les chaises." Students demonstrated understanding 
by putting their bags on the chairs. Francis asked a student in her Grade 9 applied class, "Comment s'appelle ton chanteur?" She immediately followed up with, "Il est un musicien à [sic] Toronto?" The beginner student demonstrated understanding and attempted to respond in French: "Non, Jamaïca" (pronouncing Jamaica with a French accent).

Table 4

Example of Student Comfort with and Understanding of Teacher Target Language Use: The Cases of Phyllis and Francis

\begin{tabular}{ll}
\hline Phyllis - Grade 9 Applied Core French & Phyllis - Grade 10 Academic Core French \\
\hline Phyllis: Où est Casper? Absent? & Phyllis: Qui n'ont [sic] pas encore fini le \\
Student \#5: He's photocopying. & dialogue? \\
& Student \#1: Est-ce qu'on doit fait la \\
& prochaine classe? \\
& Student \#2: Vendredi, je ne serai pas ici. \\
& Student \#3: Je suis absente le jour après... \\
& Student \#4: We have French on Thursday. \\
& Another student \#5: Never mind Madame. \\
& Student \#5: Elle a donné pour chaque \\
\hline Francis - Grade 9 Applied Core French & groupe. Elle a changé la date. \\
\hline Francis: Avez-vous choisi votre groupe & Francis: Si vous avez fini vos \\
musical? & corrections...prenez deux ou trois minutes \\
Student \#1: I don't have a band. & pour étudier le vocabulaire de chapitre 6. \\
Francis: Tu veux changer. & Student \#1: Do we just type this up? \\
Student \#2: A Bruno Mars & Francis: Non il faut faire une bonne copie... \\
Francis: Tu as besoin d'un crayon? & (Students get up for the national anthem) \\
(repeats twice and shows pencil) & Francis: Sac sur les chaises. \\
Francis: Quel artiste? & (Student understands and puts bag on chair) \\
Francis: Comment s'appelle ton & \\
chanteur? & \\
Francis: Il est un musicien à [sic] & \\
Toronto? & \\
Student \#3: Non, Jamä̈a (attempts to & \\
pronounce with French accent). & \\
\hline
\end{tabular}

On the other hand, in classes where the teacher spoke large amounts of English and primarily employed translation techniques to provide comprehensible input, I observed numerous instances of student lack of comfort with and understanding of the TL. Excerpts from Brenda's Grade 9 Applied Core French class and Grade 10 Academic Core French class demonstrate this lack of comfort and understanding (Table 5). For example, in her Grade 9 Applied class, students demonstrated uncertainty as to what the words cahier and encore meant. In Brenda's Grade 10 Academic class, one student was unsure of the meaning of the word dictionnaire while another thought the word brouillon meant soup. In her Grade 10 Academic class, a student told Brenda when she spoke French: "I don't understand." And another student bluntly asked Brenda: "Could you just explain in English?" 
Table 5

Example of Student Lack of Comfort and Understanding of Teacher Target Language Use: The Case of Brenda

Grade 9 Applied Core French Grade 10 Academic Core French

Brenda: Bonjour! To start, on va faire de la révision... So you have, if you look in your visual dictionaries, what do you do with tickets? I am about to hand them back. If you need help, tu peux chercher à la p. 98 dans ton cahier.

Student \#1: p. 98 in your cahier?

Student \#2: Yeah.

Brenda: You have to start what makes sense...

Student \#3: She said cahier.

Brenda: C'est un monologue, c'est toi et seulement...

Brenda: Si je pouvais changer le monde, je.... Student \#1: Could you just explain in English?

Brenda: Est-ce que c'est bien fait?

(Student silent; teacher reformulates)

Brenda: Vous pouvez lire le travail à haute voix? Student \#2: What?

Brenda: (asking another student) Tu veux un dictionnaire?

Student \#3: (long silence) Oh, oui.

...

Brenda: Est-ce que tu as aimé les idées de...?

Brenda: Maintenant, on va faire l'écoute... Student \#4: I don't understand.

Brenda: Est-ce qu'il faut écouter encore? Encore?

Two students: Encore? Encore means again?

Brenda: Oui.

Brenda: Votre attention - pour lundi il vous faut un brouillon s'il vous plait.

Student \#2: A what?

Brenda: Un brouillon.

Same student \#2: A soup?

Brenda: No, a rough copy.

In this section, I demonstrated the butterfly effect in the Core French classroom. Seemingly small differences in input (i.e., teacher techniques to provide comprehensible TL and promote student use of French) resulted in substantial differences in output (i.e., actual amount of TL use by the teacher and students and student level of comfort with and understanding of French). While participants in this study overwhelmingly believed in the importance of large amounts of TL use by both the teacher and students, seemingly minor differences in instructional practices meant that certain participants achieved outcomes aligned with this belief while others did not. I analyzed the transcriptions of the individual interviews to identify factors that could explain this discrepancy.

\section{Teacher Self-Efficacy: A Key Factor in Teachers Achieving Outcomes Aligned with Their Beliefs}

In analyzing the transcriptions of the individual interviews, I found significant differences in focal participants' judgments of their teaching. Those teachers who recorded high levels of TL use and whose students demonstrated comfort and understanding when spoken to in French displayed the characteristics identified by Bandura (1986) of teachers with a high degree of self-efficacy regarding their Core French teaching abilities. These characteristics include self-confidence, satisfaction with the Core French program, confidence in Core French students' abilities, spontaneity, flexibility, perseverance, and willingness to take initiative. Meanwhile, those teachers who recorded low levels of TL use and whose students demonstrated a lack of comfort with and difficulty understanding 
French displayed the characteristics of teachers with a low degree of self-efficacy in their Core French teaching. These characteristics include lack of confidence in one's abilities (self-confidence), dissatisfaction with the Core French program, lack of confidence in their students' abilities, lack of spontaneity and flexibility, and a low degree of perseverance and initiative. They expressed a strong need to plan and structure and were uncomfortable with unplanned, unforeseen, and unstructured situations. This reality explains the minimal TL use by teachers with low self-efficacy in unstructured situations such as those that did not involve the expression of routine phrases or participation in drill-type activities.

Focal participants whose TL practices were consistent with their beliefs demonstrated a high degree of self-confidence in their Core French teaching. They employed words and phrases such as "I had a successful class," "the success that I've had," and "my personality works with teaching" to describe themselves and their teaching. Focal participants whose TL practices did not coincide with their beliefs expressed a lack of selfconfidence, using words and phrases such as "I struggle, I am failing miserably and I don't know how to get them there right now" (Table 6).

Table 6

Focal Participants: Levels of Self-Confidence

Self-confidence Lack of self-confidence

Will: It's fairly typical, I think I had a very Mary: I feel like I am failing successful class today in that the activities miserably...my measure of failing we're doing; I can do almost exclusively in French... miserably is how much English they're speaking to me and how much they just bitch and complain when I speak French...

Participants whose TL practices were consistent with their beliefs demonstrated enthusiasm and optimism about the Core French program, employing words and expressions such as, "the program is very good," "it can be exciting," and "it's pretty amazing when I hear them say: Je suis désolé(e)." Focal participants whose TL practices did not coincide with their beliefs expressed far less enthusiasm, and even pessimism, about the Core French program, stating, "it's really unstructured" and "I just want to get through the book" (Table 7).

Table 7

Focal Participants: Satisfaction with the Core French Program

\begin{tabular}{ll}
\hline Enthusiasm and optimism & Lack of enthusiasm \\
\hline $\begin{array}{l}\text { Will: But for the most part, I think the } \\
\text { program is very good and has good }\end{array}$ & $\begin{array}{l}\text { Brenda: I find the Grade 10 course is } \\
\text { really, really unstructured so it's really } \\
\text { standards and expectations for the }\end{array}$ \\
$\begin{array}{l}\text { difficult to know what kind of evaluations } \\
\text { we should be doing, so I find I'm really } \\
\text { unbalanced with my Grade 10s. }\end{array}$ \\
\hline
\end{tabular}

Focal participants whose TL practices were consistent with their beliefs also expressed far greater confidence in the abilities of their Core French students, stating they were "wonderful," "very motivated," "great," "very good," and "they'll understand, no 
problem." Focal participants whose TL practices did not coincide with their beliefs expressed a lack confidence in their students' abilities. They believed Core French students know nothing, are "slow," "don't know what I'm saying" [in French], "won't understand," "would be lost" if spoken to in French, and are "very afraid of making mistakes" (Table 8).

Table 8

Focal Participants: Confidence in Students' Abilities

Expressions of confidence

Faizal: I'll be able to speak to a group of girls, they'll understand, no problem...They'll be able to produce the more they hear.
Expressions of lack of confidence

Zara: I find I have to really assume they know nothing because if I assume anything, they're lost. I have spoken French to them...but the fact is, they're slow anyway, so I didn't want to waste time.

A lot of the time I'll give instruction in French, but in my head, I'm thinking they don't know what I'm saying so I will translate that for them, even though they might. It's my perception they won't understand, so I'm doing them a favour by translating...

Francis: Both my Grade 10s are wonderful, they're very, very motivated... My Grade 9 Mary: This class is very afraid of making mistakes...

Applieds, my most motivated in my four years of teaching...my 9 Academics are great.... lot of them come from an extended French background, so they have a very, very good skill base...

Focal participants whose TL practices were consistent with their beliefs proved more flexible and spontaneous and more willing and able to handle the unexpected. They were willing to follow through with an activity even if it might not go exactly as planned, declaring, "sometimes you just have to go with it" and "the most successful lessons were the ones I planned the least!" Teachers whose TL practices did not coincide with their beliefs emphasized the need to plan and to structure everything and shared that they would shy away from spontaneous situations, discussions, or activities if they did not have the time to properly plan, organize, and structure everything (Table 9). 
Table 9

Focal Participants: Spontaneity and Flexibility

\begin{tabular}{|c|c|}
\hline Expressions of spontaneity and flexibility & $\begin{array}{l}\text { Expressions of lack of spontaneity and } \\
\text { flexibility }\end{array}$ \\
\hline $\begin{array}{l}\text { Will: sometimes you just have to go with } \\
\text { it. }\end{array}$ & $\begin{array}{l}\text { Zara: It doesn't happen spontaneously, I } \\
\text { have to plan the French part...I have to, } \\
\text { because there's no way to have a } \\
\text { spontaneous conversation...so I } \\
\text { structure everything. So sometimes, I just } \\
\text { don't do it. }\end{array}$ \\
\hline $\begin{array}{l}\text { Pauline: But sometimes that's } \\
\text { improvisational, sometimes, it's like ok... }\end{array}$ & $\begin{array}{l}\text { Brenda: I don't know, games, organizing } \\
\text { them takes a lot of work } \\
\text {...it takes a lot of work to remind yourself } \\
\text { that they should be asking this in French } \\
\text { and then remind them they should be } \\
\text { asking this in French }\end{array}$ \\
\hline $\begin{array}{l}\text { Phyllis: It's funny, the lessons I had the } \\
\text { most success with were the ones I planned } \\
\text { the least. }\end{array}$ & $\begin{array}{l}\text { Mary: I don't do them...I don't do } \\
\text { them... because I'm just... I'm too last } \\
\text { minute... }\end{array}$ \\
\hline
\end{tabular}

Focal participants whose TL practices were consistent with their beliefs insisted, "I'm not giving up," and "I don't give in to the pressure to speak English." On the other hand, teachers whose TL practices did not coincide with their beliefs employed expressions such as, "I just gave up," "sometimes I cut it off earlier than I need," and "I just stop" (Table 10).

Table 10

Focal Participants: Perseverance

\begin{tabular}{ll}
\hline Expressions of perseverance & Expressions of lack of perseverance \\
\hline $\begin{array}{l}\text { Phyllis: I don't give in to the pressure to } \\
\text { speak English because I feel it's a bit of a }\end{array}$ & $\begin{array}{l}\text { Zara: Sometimes it doesn't work sometimes } \\
\text { I cut it off earlier than I need... And then }\end{array}$ \\
$\begin{array}{l}\text { battle, they're speaking English, I'm } \\
\text { speaking French until somebody gives, but }\end{array}$ & $\begin{array}{l}\text { we're trying to name him, they were having } \\
\text { so much disagreement, I just gave up. }\end{array}$ \\
$\begin{array}{l}\text { it's not going to be me. } \\
\text {...this one [game] flopped because I didn't } \\
\text { have the dice, but I'm not giving up. }\end{array}$ \\
\hline
\end{tabular}

According to the theory of self-efficacy, judgement of one's ability to achieve an outcome is more important than actual ability. Judgement of one's ability to achieve an outcome in the face of chaos - an inevitable part of operating within any complex nonlinear system such as the Core French classroom - is a defining factor in consistency or inconsistency between teacher beliefs and practices. Teachers with a high degree of selfefficacy do not necessarily possess greater knowledge about Core French teaching approaches, methodologies, activities, and lesson planning. However, they have greater confidence in their ability to handle periods of chaos, to implement an approach 
successfully, and to achieve a desired outcome. To demonstrate how a hybrid conceptual lens of complexity theory and the theory of self-efficacy can provide a unifying framework for better understanding the relationship between teacher beliefs and their instructional practices, the next section contains a case study of two of the focal participants: Phyllis and Brenda.

\section{Putting it All Together: A Case Study of Focal Participants Phyllis and Brenda}

Brenda and Phyllis had similar profiles. They were both beginning teachers. They were young women in their mid- to late 20s. Their first/dominant language was English. They had completed the Core French program as students in Ontario. They had similar proficiency levels in French. Both had spent time in France. Neither had had a positive experience as a Core French student. Brenda had a negative practicum experience, while Phyllis had a mixed reaction to her practicum experience. They were former students of mine who taught full time in a secondary school specializing in the arts (i.e., drama, dance, music). Brenda and Phyllis had similar FSL timetables, as each was teaching at least one Grade 9 Applied Core French class, one Grade 9 Academic class, and one Grade 10 Academic class. Phyllis had completed 2 years of Core French teaching, while Brenda was in her first year. They held similar beliefs regarding the objectives of the Core French program, notably that French should be the primary language of communication in the classroom and that students should interact as much as possible in the TL.

During their lessons, Brenda and Phyllis corrected homework in the same textbook with a Grade 9 Academic Core French class. Both teachers employed a similar instructional practice to the homework correction wherein the teacher attempted to lead the homework correction in French, asking individual students to contribute answers. Brenda began the lesson by telling her students in French, "On va corriger les devoirs" and asking them, "Sortez-vos cahiers s'il vous plait" and "Est-ce que tu veux sortir ton cahier?" Phyllis began her lesson by asking students to turn to the appropriate page in the textbook: "Le devoir dans le cahier page 88 Sans Frontières $9^{e}$." Initial conditions in both cases were disrupted by a period of chaos or instability. In each case, a student interrupted the teacher in English, demonstrated a lack of understanding, or even explicitly insisted the teacher switch to English. In Brenda's case a student said, "I have no idea what you said." In Phyllis' case, the student interrupted her with, "Can I get a drink?" These situations presented challenges for both Brenda and Phyllis. Faced with navigating these challenges, it is here that the behaviours/reactions of Brenda and Phyllis diverged and we observe the results of the butterfly effect.

A detailed analysis of Brenda and Phyllis' reactions or behaviours reveals small but crucial differences in how they responded to these challenges, or how they navigated the chaos. While Phyllis used French throughout the lesson, employing visual aids, gestures, and intonation to make herself understood, she explicitly insisted that her students speak in French through prompts such as "Pourquoi tu parles anglais?" and provided positive encouragement to this end: "Tu es capable!" She also scaffolded the language for students and modeled how to respond in French. For example, in one case she supplied a word or expression when a student said "Est-ce que je peux go get my crayon?" Phyllis added "chercher." In another instance, Phyllis translated a student's sentence into French. When the student said, "I can't find my copy," Phyllis translated, "Je ne peux pas trouver ....." 
Brenda also began correction of the homework in French, through stating "On $v a$ corriger les devoirs. Sortez-vos cahiers s'il vous plait." However, when a student insisted that he or she did not understand by saying, "I have no idea what you said," Brenda immediately switched to English to communicate not just with that student but with the entire class. She switched to saying “. . . we did E let's take up E. Some of you had trouble with F." Brenda did not use any visual aids, gestures, or intonation to help the student understand. When students spoke or responded in English, I did not observe any instances of Brenda explicitly requesting that students speak French.

These seemingly small differences in how Brenda and Phyllis navigated the chaos led to substantial differences in output/outcome; that is, after the chaos, while Phyllis' instructional practices around TL use remained consistent with her beliefs, Brenda's did not. In Phyllis' class, there is evidence that the teacher and students were quite comfortable with the teacher employing French as the language of communication. For example, Phyllis asked, "Est-ce que vous avez des copies de la rubrique pour madame?" Even if the student responded in English, it was without any obvious hesitation: "I can't find my copy." There were no instances of students protesting or opposing teacher use of the TL. Perhaps the students in Phyllis' class had come to expect that the teacher would scaffold their understanding with visual aids, gestures, and intonation (e.g., showing the rubric when asking, "Est-ce que vous avez des copies de la rubrique pour madame?"). Perhaps they were more likely to attempt to answer in French knowing that their teacher would insist that they try to use the TL (e.g., "Pourquoi est-ce que tu parles anglais?"), that she would provide positive reinforcement (e.g., "Tu es capable!"), and, most importantly, that she would model how to respond and scaffold their responses if they required help (e.g., modeling for students how to say in French, "Je ne peux pas trouver ..."). In Brenda's class, the outcome was several observed instances of discomfort by both teacher and students with the use of French as the primary language of communication (e.g., "I have no idea what you said; Could you just explain in English.") with Brenda switching to English whenever a student did not understand.

During her individual interview, Phyllis displayed the characteristics of a teacher with a high degree of self-efficacy about her ability to employ the TL. She demonstrated preparedness to deal with the chaos, whether it be a student pressuring her to speak English, a student requiring support to understand her use of the TL, or a student needing help to respond in French. She admitted that there was pressure to speak English in her Core French classes and that "it's a lot of energy" to speak French, but she expressed a high level of self-efficacy in her ability to handle the pressure. Phyllis stated, "they're speaking English, I'm speaking French until somebody gives, but it's not going to be me." She regularly employed visual aids — or cues, as she called them — to help students understand her use of French. She said, "I continuously go point at the poster . . . I ha[ve] all those visual cues, I think those are important."

Phyllis recognized the importance of certain small behaviours and actions such as "connecting with the students," "caring about them," "asking them about themselves," and "asking about what they do on the weekends as so key to getting them to buy in, and they have to buy in." She understood that the little things make a big difference. She also emphasized the need to scaffold the language for her students to help them respond in the TL. Phyllis said, "I find that if you can explain it in French, if you start simply . . in steps, that you can really do it in French, but if you can really start from something that they know." She even went on to say, "It's a scaffolding thing." 
In contrast, Brenda displayed the characteristics of a teacher with a low degree of self-efficacy about her ability to employ the TL. She admitted that when a student responded in English she tended to switch to English as she found it hard "to not answer questions in English when I've been asked them in English." She acknowledged that "it's really hard to come in and to remember to speak in French" that "it takes a lot of work to remind yourself that they should be asking this in French and then remind them they should be asking in French and encourage them to keep trying." She provided an instance of a student capable of speaking French who that day (when I was observing) insisted on speaking English and how she found it "odd he didn't switch" even though she was addressing him in French. However, during the lesson, she did not explicitly ask the student to switch to French. Furthermore, it did not occur to her during the post-observation interview that explicitly asking the student to speak French and encouraging him to do so might have provided sufficient motivation for him to switch languages.

While the above would seem obvious to an outside observer, when under pressure the small things such as the teacher continuing to speak French when students are responding in English or insisting that the teacher speak English can prove very difficult. This difficulty may be particularly acute for a teacher with low self-efficacy about their ability to employ the TL who has not consciously prepared herself to handle such a situation. In Brenda's own words, "I definitely didn't have a plan, that's something to think about."

Phyllis developed her own set of French expressions to encourage her students. For example, she called them superstars with a French accent and intonation when they had done well. Meanwhile, Brenda admitted that there was "a lot of anxiety" when she began teaching Core French and reflected, "I think I still struggle." She found it "hard to remember to speak French" with her students or not to respond to her students in English when they addressed her in English.

What factors can account for the discrepancy between Phyllis and Brenda in levels of self-efficacy? Brenda was in her first year while Phyllis was in her third year. ${ }^{4}$ Phyllis had spent time teaching English as a foreign language (EFL) in France. Even in France, she had demonstrated initiative, stating that she was always looking at course outlines and "getting information from schools about what their philosophy is and what their approach is to learning languages." Phyllis had also studied several other foreign languages, including Russian, Spanish, and Croatian. She shared that these varied language-learning experiences informed her Core French teaching. She also shared that during her teacher education program, she was convinced vicariously and via verbal persuasion that she could teach in the TL. As she said, "I guess I never thought that was possible before but, I was told it was possible so I believed it was."

In the case of Brenda, her only language learning and teaching experiences were related to the French language. Neither verbal persuasion nor vicarious experiences during her teacher education program had convinced Brenda that she could successfully communicate primarily with students in the TL and have her students regularly attempt to respond to her in French. Regarding teacher's college, she stated that "it was always in the back of my head what I should be doing," "what the ideal practice is." However, she expressed regret at not being able to remember the activities discussed during her teacher education program and wished she had "been told in the beginning of the year to write down what they were." 
In the concluding sections of the paper, I summarize the results of the study and highlight the contributions. I also discuss the limitations of the study and implications for FSL teacher education, and make suggestions for future research.

\section{Summary of Results}

\section{What was the profile of the participants in the study?}

In the questionnaire data, the profile of participants was found to be the following: all participants taught in an Ontario public school; participants were primarily teaching Grade 9 Core French; they were predominantly female and working full-time; French was a second or third language and English was the dominant language; almost all had completed their schooling in a Core French or French Immersion program in Ontario; and the majority were in their first 5 years of teaching.

\section{What were participants' beliefs about second language teaching, Core French programs and communicative language teaching (CLT)?}

In the questionnaire, participants were found to hold similar beliefs about Core French teaching. They overwhelmingly believed that the focus of Core French instruction should be on listening and speaking; that large amounts of TL input are essential to learning French; and that student interaction in the TL and learning about the TL cultures are crucial. They were enthusiastic to employ CLT.

\section{What were their declared practices?}

Teachers in the questionnaire declared that their Core French teaching practices were most often teacher-centred, grammar-focused, and concentrated around lessons and exercises in textbooks/workbooks approved by the province. They declared that their use of the TL was significant for use of routine phrases and in highly-structured situations and less significant in unstructured situations and when explaining a new concept, a test and an assignment.

\section{How did the actual practices of participants compare with their declared practices?}

During the classroom observations, the teaching practices of the 13 focal participants were found to be very similar. The practices identified by teachers in the questionnaire were: teaching was mostly teacher-centred, lessons were often grammarfocused, and use of textbooks and workbooks was prevalent. They declared that they always or almost always employed the TL for routine phrases and in highly-structured situations, while they less frequently employed the TL in unstructured situations and to explain a test or assignment.

A detailed analysis of TL practices in the classroom observation notes revealed that focal participants either employed exclusively or almost exclusively the TL or that they employed English almost exclusively. Teachers who employed techniques such as gestures, visual aids, intonation, multiple choice, and "or" questions were those who employed 
exclusively or almost exclusively the TL with their Core French students regardless of grade or program, while those who did not employ such techniques were those who spoke almost exclusively in English regardless of grade or program. Students in classes where the teacher employed large amounts of French were found to employ larger amounts of French themselves and even where their students were observed responding in English, these same students demonstrated comfort and understanding when the teacher spoke French.

\section{What were participants' perceptions/impressions of their practices and how did this affect their instructional practices?}

Focal participants who employed exclusively or almost exclusively the TL in their

Core French classrooms were also the teachers during the individual interviews who displayed the characteristics of teachers with a high degree of self-efficacy in their Core French teaching: self-confidence, satisfaction with the program, confidence in their students' abilities, spontaneity, flexibility, perseverance, and willingness to take initiative. Meanwhile, focal participants who recorded low levels of TL use displayed the characteristics of teachers with a low degree of self-efficacy in their Core French teaching. These characteristics included lack of confidence in one's abilities (self-confidence), dissatisfaction with the program, lack of confidence in their students' abilities, lack of spontaneity and flexibility, and a low degree of perseverance and initiative. They expressed a strong need to plan and structure and were uncomfortable with unplanned, unforeseen, and unstructured situations. This can help to explain lack of TL use by these teachers, especially in unstructured/new situations.

\section{Contributions to the Field of Second Language Teaching and Learning}

This study provides a significant contribution to theoretical knowledge in the field of Core French teaching, FSL, and second language teaching in general. Analyzing data on Core French teacher beliefs and practices through the lens of complexity theory and the theory of self-efficacy enabled me to answer my two primary research questions:

1. What is the relationship between Core French teachers' beliefs and their instructional practices?

2. What factors affect the relationship between Core French teachers' beliefs and their instructional practices?

While the majority of the teachers in this study were found to have TL practices aligned with their beliefs, a minority of participants' TL practices did not align with their beliefs. Teachers' navigation of periods of instability and uncertainty — known as chaos in complexity theory - was found to be crucial in understanding consistency/inconsistency.

A case study of two focal participants demonstrated how in the face of chaos two Core French teachers' attempts to employ an instructional practice consistent with their beliefs - that is, lead the correction of homework in a textbook/workbook in the TLresulted in one teacher's TL practices remaining aligned with her beliefs while the other teacher's TL practices were no longer consistent with her beliefs. The teachers began with similar initial conditions: same grade, textbook/workbook, class size, activity, and approach. A seemingly small disruption, that is, a student demonstrating lack of 
understanding when the teacher spoke in French and/or demonstrating discomfort when spoken to in French led to a period of chaos, demonstrating the sensitivity of the Core French classroom to minor changes in initial conditions. Faced with a student who was uncomfortable being spoken to in French, one teacher handled the situation with the use of gestures, intonation, multiple-choice questions, and "or" questions She continued communicating with her students in French, while the other focal participant translated and switched to English. This is evidence of the butterfly effect, where seemingly tiny differences in input (e.g., use of gestures, intonation) can become overwhelming differences in output (the teacher teaching the class exclusively or almost exclusively in French versus almost exclusively in English).

Teacher levels of self-efficacy are important to understanding the choices teachers make in navigating chaos. The findings of this study point to the fact that self-efficacy-a judgement of one's ability to achieve an outcome, specifically, the ability to meet any challenges and to complete a task successfully_is as important, if not more important, than actual ability.

I found levels of self-efficacy to be key in explaining why the two teachers handled the chaos so differently. The teacher who employed gestures, intonation, visual aids, and questioning techniques when faced with student lack of understanding of French displayed in her individual interview the characteristics of a teacher with a high degree of selfefficacy about her ability to employ the TL. In contrast, the teacher who switched to English displayed in her individual interview the characteristics of a teacher with a low degree of self-efficacy about her ability to employ the TL. Differences in the two teachers' enactive and vicarious experiences and the impact of verbal persuasion may account for the discrepancy in levels of self-efficacy. However, this was beyond the scope of this study.

\section{Limitations of the Study}

With only 47 participants having completed the questionnaire and 13 participants having participated in the classroom observations and individual interviews, this study did not seek to provide generalizations about Core French teachers' beliefs about Core French teaching or their teaching practices. Rather, the objective was to capture the thoughts and behaviours of a select group of Core French teachers to provide insight into the relationship between their beliefs and practices and the factors affecting their ability to maintain practices consistent with their beliefs. Another limitation of the study is the possibility of a response bias due to social desirability in both the questionnaires and individual interviews. Participants may have provided what they believed to be the "desirable/ acceptable/expected answer" (Dörnyei, 2003, p. 12) to questions about the best way to teach Core French, the role of the TL in the Core French classroom, and how they felt about CLT. Participants were aware of my personal biases and this may also have influenced their answers. Another limitation of this study is that classroom observations involved a maximum of 2 or 3 days within the same week with each participant. It would have been ideal to observe teachers for 2 to 3 days at the beginning of the year and at the end of the year. A longitudinal case study would allow for collection of data throughout the process of implementing a new instructional practice. 


\section{Implications for FSL Teacher Education}

As Piccardo (2010) asserted, complexity should be at the core of all FSL teacher education programs. Future second language teachers would benefit greatly from a teacher education program that prepares them for the unpredictable, uncertain, human dimension of teaching, not just a program where teacher educators present different second language approaches, methodologies, activities, and materials (Piccardo, 2010). If beginning Core French teachers are to adopt successfully new instructional approaches, which they were enthusiastic to do in this study, it is vital that they understand that teaching is first and foremost a complex activity. It is important that they learn to be adaptable, flexible, and spontaneous in the face of periods of chaos. In FSL teacher education programs, teacher candidates, via discussion and role play, could explore different scenarios involving periods of chaos in the Core French classroom along with strategies and techniques to navigate these periods of chaos. They could discuss possible difficulties/challenges they might encounter with the introduction of an approach or activity. Candidates could anticipate the consequences of choosing a specific strategy or technique.

Teacher education programs for FSL must also address teacher levels of selfefficacy. It should be noted that three of the four focal participants in this study who displayed the characteristics of individuals with low levels of self-efficacy regarding their Core French teaching left Core French teaching after this study. It is essential that beginning teachers be afforded opportunities to engage in positive, enactive, and vicarious Core French teaching experiences. It is vital that beginning teachers work with host and mentor teachers who help them understand and deal with the complexities of teaching, who provide them with much-needed verbal and social persuasion during their practicums (e.g., "You can do it!" and "It is possible"). For example, teacher candidates and beginning teachers require host and mentor teachers who can provide guidance on and demonstrate how to effectively handle Core French students who insist that the teacher speak English, students who refuse to attempt to speak the TL, or students who are exposed in the home to the view that learning French is a waste of time. Teacher candidates and beginning teachers require host and mentor teachers who will share advice, strategies, and techniques on the small but hugely important things such as how to negotiate student feelings of discomfort, uncertainty, and anxiety in the face of a new language. Moreover, teacher candidates need to learn how to provide comprehensible TL input to beginner students, how to negotiate meaning without translation, and how to encourage students to make the effort to communicate in the TL with the teacher.

In short, this study can assist Core French teachers in successfully implementing new and desired approaches (e.g., CLT and an action-oriented approach) and activities. Most importantly, it can help teachers ensure greater consistency between beliefs and practices and thus meet their objectives for their Core French teaching. As well, the study can provide a framework for teacher educators, host teachers, and mentor teachers so that they may offer effective supports and materials to teacher candidates and beginning Core French teachers.

\section{Suggestions for Future Research}

Further research is required to determine how teacher education programs and inservice professional development opportunities can best prepare Core French (FSL) 
teachers to understand the complexities of teaching and handle periods of chaos. Further study is also required to gain a deeper understanding of the types of chaos Core French teachers face, what sorts of chaos might ensue based on the introduction of an instructional approach or activity, and what sorts of strategies and techniques can be effective in navigating the different types of chaos. It is also important to better understand what factors contribute to higher levels of teacher self-efficacy. Research could examine the types of enactive and vicarious experiences, and verbal/social persuasion that contribute to higher levels of self-efficacy and best prepare teachers to handle chaos. Further study is required to better understand how and why certain individuals benefit greatly from vicarious experiences and verbal/social persuasion, while others secure less benefits from the same experiences. Finally, it is important to further explore the relationship between teacher understanding of and preparedness for the complexities of teaching and their levels of selfefficacy. Additional research could explore whether increased understanding of the complexities of teaching and the types of strategies and techniques used to handle chaos contribute to greater levels of self-efficacy.

Correspondence should be addressed to Usha Viswanathan.

Email: uviswanathan@glendon.yorku.ca

\section{Notes}

${ }^{1}$ All data for this study were collected during the period 2012-2014. However, I remain in contact with many of the participants.

2 The AIM program was developed specifically for Core French by Maxwell. Maxwell, a Core French teacher in Vancouver, was frustrated with the results of traditional approaches to Core French teaching. One of the key expectations of the AIM program is that instruction be in French all the time. The program relies on the use of: "a controlled vocabulary accompanied by gestures ... rehearsed in plays and later becomes the basis for communication in the classes once the students have gained some ease with the words and expressions" (Majhanovich \& Smith, 2010, p. 25).

${ }^{3}$ Percentages in Figures 1, 2, and 3 do not add to 100 as coverage was calculated from the researcher's hand-written observation notes, which included descriptions of teacher and student behaviour (gestures, intonation, visuals, students seated in rows versus in groups). The idea was to provide a rough visual of the ratio of French to English.

${ }^{4}$ It must be noted that I observed both during their practicums and that their teaching practices/behaviours had not changed when I observed them for this research study.

\section{References}

Allinder, R. M. (1994). The relationship between efficacy and the instructional practices of special education teachers and consultants. Teacher Education and Special Education, 17(2), 86-95.

Bandura, A. (1977). Self-efficacy: Toward a unifying theory of behavioural change. Psychological Review, 84(2), 191-215. 
Bandura, A. (1982). Self-efficacy mechanism in human agency. American Psychologist, $37(2), 122-147$.

Bandura, A. (1986). Social foundations of thought and action: A social cognitive theory. Englewood Cliffs, NJ: Prentice Hall.

Bandura, A. (1997). Self-efficacy: The exercise of control. New York, NY: W. H. Freeman and Company.

Bandura, A. (2006). Guide for constructing self-efficacy scales. In F. Pajares \& T. Urdan (Eds.), Self-efficacy beliefs of adolescents (pp. 307-337). Greenwich, CT: Information Age Publishing.

Basturkmen, H. L. (2012). Review of research into the correspondence between language teachers' stated beliefs and practices. System, 40, 282-295.

Basturkmen, H. L., Loewen, S., \& Ellis, R. (2004). Teachers' stated beliefs about incidental focus on form and their classroom practices. Applied Linguistics, 25(2), 243-272.

Burley, W. W., Hall, B. W., Villeme, M. G., \& Brockmeier, L. L. (1991, April). A path analysis of the mediating role of efficacy in first-year teachers' experiences, reactions, and plans. Paper presented at the annual meeting of the American Educational Research Association, Chicago, IL.

Calman, R., \& Daniel, I. (1989). A board's eye view of Core French: The North York Board of Education. In S. Lapkin (Ed.), French second language education in Canada: Empirical studies (pp. 283-325). Toronto, Canada: University of Toronto Press.

Chacon, C. (2005). Teachers' perceived efficacy among English as a foreign language teachers in middle schools in Venezuela. Teaching and Teacher Education, 21(3), 257-272.

Creswell, J. W., \& Plano Clark, V. L. (2011). Designing and conducting mixed methods research. Los Angeles, CA: Sage.

Dellinger, A. B., Bobbett, J., Olivier, D., \& Ellet, C. (2008). Measuring teachers' selfefficacy beliefs: Development and use of TBS-Self. Teaching and Teacher Education, 24(3), 751-766.

Dörnyei, Z. (2003). Questionnaires in second language research: Construction, administration and processing. Mahwah, NJ: Lawrence Erlbaum.

Faez, F., Majhanovich, S., Taylor, S., Smith, M., \& Crowley, K. (2011). The power of "can do" statements: Teachers' perceptions of CEFR-informed instruction in French as a second language classrooms in Ontario. Canadian Journal of Applied Linguistics, 14(2), 1-19.

Fang, Z. (1996). A review of research on teacher beliefs and practices. Educational Research, 38(1), 47-65.

Frolich, M., Spada, N., \& Allen, P. (1985). Differences in the communicative orientation of L2 classrooms. TESOL Quarterly, 19(1), 27-57.

Gabillon, Z. (2012). Revisiting foreign language teacher beliefs. Frontiers of language and teaching, 3, 190-203.

Gibson, S., \& Dembo, M. H. (1984). Teacher efficacy: A construct validation. Journal of Educational Psychology, 76(4), 569-582.

Gleick, J. (1987). Chaos: Making a new science. New York, NY: Penguin.

Glickman, C., \& Tamashiro, R., (1982). A comparison of first-year, fifth-year, and former teachers on efficacy, ego development, and problem solving. Psychology in Schools, 19(4), 558-562. 
Graden, E. C. (1996). How language teachers' beliefs about reading instruction are mediated by their beliefs about students. Foreign Language Annals, 29(3), 387-395.

Greene, J. C. (2007). Mixed methods in social inquiry. San Francisco, CA: Jossey-Bass.

Guskey, T. R. (1988). Teacher efficacy, self-concept, and attitudes toward the implementation of instructional innovation. Teaching and Teacher Education, 4(1), 63-69.

Howard, J. (2006). Report for the Canadian Association of Second Language Teachers relating to the survey of core French and French immersion teachers: Data tabulation and analysis of open-ended questions 31 and 38. Ottawa, Canada: Canadian Association of Second Language Teachers.

Lapkin, S., MacFarlane, A., \& Vandergrift, L. (2006). Teaching French in Canada: FSL teachers' perspectives. Ottawa, Canada: Canadian Teachers' Federation.

Lapkin, S., Mady, C., \& Arnott, S. (2009). Research perspectives on Core French: A literature review. Canadian Journal of Applied Linguistics, 12(2), 6-30.

Larsen-Freeman, D. (1997). Chaos/complexity science and second language acquisition. Applied Linguistics, 18(2), 141-165.

Levine, G. S. (2003). Student and instructor beliefs and attitudes about target language use, first language use, and anxiety: Report of a questionnaire study. Modern Language Journal, 87(3), 343-364.

Lorenz, E. N. (1963). Deterministic nonperiodic flow. Journal of the Atmospheric Sciences, 20(2), 130-141.

Maestre, J. T., \& Gindidis, M. (2016). Teachers' beliefs, practices and challenges in using communicative language teaching (CLT) in an ESL context in the Philippines. The Asian Conference on Language Learning 2016 Official Conference Proceedings.

Majhanovich, S., \& Smith, M. (2010). Research report for the 2007-2009 Projet à Québec. Ottawa, Canada: The Ontario Modern Languages Teachers' Association.

Manzano, B.A. (2015). English teachers' beliefs, practices, and problems encountered in using communicative language teaching (CLT). International Journal of Education and Research, 3(3), 549-560.

Mollica, A., Phillips, G., \& Smith, M. (2005). Teaching and learning French as a second language: Core French in the elementary schools of Ontario. Ottawa, Canada: The Ontario Modern Languages Teachers' Association.

Navarro, D., \& Thornton, K. (2011). Investigating the relationship between belief and action in self-directed language learning. System, 39, 290-301.

Piccardo, E. (2010). L'enseignant un stratège de la complexité : quelles perspectives pour la formation? In G. Baillat, D. Niclot, \& D. Ulma (Eds.), La formation des enseignants en Europe : approche comparative (pp. 79-98). Brussels, Belgium: de Boeck.

Pinnegar, S., \& Carter, K. (1990). Comparing theories from textbooks and practicing teachers. Journal of Teacher Education, 41(1), 20-27.

Podell, D., \& Soodak, L. (1993). Teacher efficacy and bias in special education referrals. Journal of Educational Research, 86(4), 247-253.

Rehner, K. (2017). The CEFR in Ontario: Transforming classroom practice. CEFR/DELFrelated professional learning impact report. Retrieved from https://transformingfsl.ca/wp-content/uploads/2017/12/LGY769-DELF-1.pdf 
Richards, E. (2002). Positioning the elementary core French teacher: An investigation of workplace marginality (Unpublished doctoral dissertation). Ontario Institute for Studies in Education, University of Toronto, Toronto, Canada.

Richardson, V., Andres, P., Tidwell, D., \& Lloyd, C. (1991). The relationship between teachers' beliefs and practices in reading comprehension instruction. American Educational Research Journal, 28, 559-586.

Salvatori, M. (2008, December). The core of the matter. Change is the constant for French as a second language in Ontario. Professionally Speaking.

Siwatu, K. O. (2007). Preservice teachers' culturally responsive teaching self-efficacy and outcome expectancy beliefs. Teaching and Teacher Education, 23(7), 1086-1101.

Tschannen-Moran, M., \& Woolfolk Hoy, A. (2001). Teacher efficacy: Capturing an elusive construct. Teaching and Teacher Education, 17(7), 783-805.

Viswanathan, U. (2016). Exploring the relationship between core French teachers' beliefs and their instructional practices (Doctoral dissertation). Retrieved from https://tspace.library.utoronto.ca/bitstream/1807/77424/3/Viswanathan_Usha_2016 11_PhD_thesis.pdf 